\title{
Board Gender Diversity and Corporate Cash Holdings: Evidence from China
}

\author{
Gehui Cheng ${ }^{1, a, \uparrow}$ Lingyu Wang $^{2, b, \dagger}$ Bingyuan Xiang ${ }^{3, c, \uparrow}$
}

\author{
${ }^{1}$ Division of Business and Management, Beijing Normal University Hong Kong Baptist University United \\ International College, China \\ ${ }^{2}$ Accounting and Finance, King's College of London, the UK \\ ${ }^{3}$ School of Information Engineering, Hangzhou Dianzi University of China, China

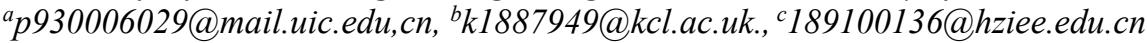 \\ These authors contributed equally.
}

\begin{abstract}
As gender diversity is increasingly valued in corporate governance, we investigate the impact of board gender diversity on corporate cash holdings. We infer a positive correlation between board gender diversity and corporate cash holdings. Combining single factor analysis and baseline regression analysis, we find that for companies with a smaller cap, lower Tobin's Q, lower leverage, and higher book-to-market ratio, higher asset returns are related to higher cash holdings. We further analyze the heterogeneity, adding the factors of whether the company is a stateowned enterprise and whether the company is audited by the Big 4 and find that female directors in non-state-owned enterprises are more significant because the financial status of state-owned enterprises is more stable. At the same time, the impact of female directors in companies that are not audited by the Big 4 is more significant. Our study contributes to the literature in the field of board gender diversity and reinforces the evidence that female directors have an indisputable impact on company financial performance.
\end{abstract}

Keywords: gender diversity, corporate cash holdings, corporate governance.

\section{INTRODUCTION}

Board gender diversity is defined as the presence of female directors on the board of directors of companies [1]. It is a significant factor in strengthening the internal governance mechanism, enhancing the supervisory function of the board of directors, and helping to reduce agency problems [2].

Nowadays, most of the capital markets around the world issued relevant regulations related to board gender diversity in listed companies. For example, Norway can be regarded as a pioneer in promoting board gender diversity. In 2008, Norway requires listed companies to have at least $40 \%$ of women's seats on the board of directors. Otherwise, they will face dissolution. In the next five years, more than 12 countries, mainly Western European countries like Iceland, Finland, etc., have adopted a similar quota system [3]. On November 20th, 2013, the European Parliament voted to pass a draft law requiring that by 2020 , the proportion of female board members of about 5,000 listed companies in the EU will reach $40 \%$; state-owned enterprises
(SOEs) will be forced to comply with the regulations before 2018 [4]. On 30th August 2018, the California Senate passed a bill requiring public companies headquartered in California to have at least one female director by the end of next year. By 2021, they will be required to give women at least $40 \%$ of board seats. This urges California to be the first state in the United States to require gender diversity on corporate boards [5]. The Nordic countries and the United States are obviously effective in promoting gender diversity on the board of directors. According to the Economist's Glass Ceiling Index is 2020, the proportion of women on the board of directors in these countries is very considerable, especially in the Nordic countries. This also verifies that the influence of female directors is increasingly recognized, and more studies on the relationship between gender diversity of the board of directors and company performance emerge.

There are a lot of valuable previous studies exploring the impact of board gender diversity on corporate performance. Campbell (2019) used Indian companies as sample data and found through research 
that female CEO companies are positively correlated with corporate cash holdings and can increase cash holdings through innovation intensity [6]. After analyzing Taiwanese companies, the result of the study indicates that concurrently serving as female directors is a key factor in improving corporate governance performance [7]. In addition to the studies mentioned, most studies have given positive feedback, which has greatly increased our confidence in this study, and we hope to bring a brand-new result and conclusion.

Because the capital market is imperfect, companies need to reserve cash to confront risks and participate in investment [8]. As corporate cash holdings increase year by year, scholars have also begun to study the factors that affect them. Many factors affect cash holdings. Studies have shown an incentive convergence effect between management holdings and cash holdings, and companies whose CEOs also serve as COBs hold significantly more cash [9]. Another notable conclusion is that the agency issue is an important factor in determining corporate cash holdings. In countries with weaker shareholder protection, investors cannot force managers to spit out excessive cash balances [10]. Additionally, company size, cash flow changes, and leverage are all factors that determine cash holdings [11]. The purpose of our study is to examine the impact of board gender diversity on the level of corporate cash holdings, which can be seen as a novel perspective.

To the best of our knowledge, we find two studies on China and the US respectively came to the opposite relationship between female directors and cash holdings. According to Zeng and Wang, they utilize a sample of 468 Chinese listed firms with female CEOs and a matched sample of firms with male CEOs during 20072011 [12]. Their empirical results reached that female CEOs have a positive correlation with cash holdings because females care less about the opportunity cost of cash. They also find those female CEOs are more concerned with the precautionary motive of cash compare with their male counterparts. What's more, females' moderation effect on the over-investment problem of free cash flow indicates more conservation than their male counterparts.

Nevertheless, on the other side, the paper of Atif (2019) studies out that board gender diversity has a significant negative relationship with cash holdings because of the distinction between the corporate governance structure of China and the US [2]. As for their research in the US, by analyzing their samples from the S\&P 1500 index firm in the US for 2006-2015, Atif and his group find a strong negative effect of female independent directors consistent with monitoring function. And according to the critical mass theory, they also reach the results of the negative effect of female directors' presence and voice on cash holding [2].
Both two studies have a limit as they didn't consider the impact of a different culture on gender problems. Especially the influence of the three cardinal principles and five permanent principles of Confucian culture, which has ruled China for two thousand years, on the thought of male superiority and female inferiority. This historical factor will lead to a very different conclusion in China in comparison to other countries. In addition, for Zeng's researches in China provided, they are still limited by the small sample size of only 974 compared to 1,395 samples of Atif's research. At a time of renewed emphasis on the feminism movement, the sample they took was a little out of date, which the period of it is 2007 to 2011. What's more, according to Carter, the firms with two or more female corporate board members perform better, as measured by Tobin's $\mathrm{Q}$, and do not generate a lower return on assets [1]. Additionally, studies show that females are not less successful at investing than males [13]. Martin, Nishikawa, and Williams find changes in risk following CEO appointments are significantly lower for female CEOs. It supports the view that the market perceives female CEOs to be relatively risk averse. Also, it finds evidence consistent with firms with relatively high risk (total risk and idiosyncratic) are more likely to appoint female CEOs so that risk might decrease, which will lead to an increasing of cash holdings [14]. All these concerns have not been considered in the prior study. Hence, we acknowledge that the results of this research will be different in different countries. Simultaneously, we improve the research of Zeng and Wang by selecting a wider range of 2,408 samples for 2011 to 2017 and employing the correlation analyses to test and examine whether gender diversity affects the corporate cash holdings in China.

Our studies employ the panel of companies listed on the Shanghai Stock Exchange (SHSE) and the Shenzhen Stock Exchange (SZSE) during the period from 2011 to 2017. Our results show that gender diversity will lead to a significant increase in corporate cash holdings. We also find that firms with female directors have lower financial leverage than those without female directors, supporting the prior studies about the high risk averse of female CEOs [14]. Our conclusion remains statistically similar even after controlling for variations in independent variables. Furthermore, we test the impact of firm fixed effects and the different measures of corporate cash holdings on our results, and finally, we get the same conclusion. Moreover, we also test the heterogeneity of our results under different conditions. Our heterogeneity analysis finds that the positive relationship between female directors and cash holdings is more pronounced for non-SOEs and firms audited by Big 4 auditors.

For the reason of selecting China's stock market as our samples, two main significant factors drive us to do this research, including the market system and history of 
female thought in China. First of all, as the biggest socialist country and biggest developing country globally, China has a unique market system that is dominated by public ownership, which leads to a lower level of board independence. Unlike the developed markets commonly seen in Western countries such as the US, China has a unique socialist market system. Furthermore, the Chinese market has become more cautious and risk averse after the 2007 A-Shared stock market crash.

Meanwhile, China is one of the world's oldest countries. Its Confucian thought of male superiority and female inferiority has influenced China thousands of years, which leads to a high glass ceiling to the females in career. Paradoxically, it is easy to find a Chinese woman who it difficult to have a job when she reached the age of pregnancy. Given that some studies have already examined the relationship between gender diversity and corporate cash holdings, it is more meaningful to explore studies in China. We could further reach the evidence to compare similarities and differences between China and other countries. Worldwide academia, there is no reason for the practitioners and policymakers to failing to pour their attention into this unique circumstance in China.

This paper contributes to the literature in three ways. First, we extend the recent body of gender diversity literature by providing strong empirical evidence (based on large panel data) of the positive impact of board gender diversity on cash holdings - a key corporate decision consistent with the agency theory.

Second, this paper contributes to inspire the management method of firms. On account of traditional concepts of women not being able to work in China, the proportion of females on the board is still very low nowadays. Based on our study, firms should increase gender diversity to balance the constructure of the board, to guarantee relatively stable cash holdings, which is extremely vital for firm management.

Finally, our study also contributes to filling in the research gaps of the impact of board gender diversity on cash holdings in China. According to our research, we discover that cash holdings are more sensitive in nonSOEs and non-Big 4 firms when increasing gender diversity, which gives a partial solution on adjusting gender diversity in different types of firms.

\section{HYPOTHESIS DEVELOPMENT}

Previous studies unfold the importance of appointing females as CEOs, such as high-quality decision-making and strong monitoring by innovative perspectives to solve complex issues [15]. Abbott also finds a negative relationship between female directors and the likelihood of financial restatement due to the female could help maintain the attitude of mental independence [16].
These advantages of female directors could help firms use the cash more efficiently and decrease the cash holding to make a good investment. However, there is also a body of literature that would predict the risk aversion of female directors, which will lead to an increasing in cash holdings. Females have a lower preference for risk in decision-making compared to males [17]. Jianakoplos and Bernasek find females are more conservative investors in that they have smaller proportions of their portfolios invested in risky assets than males [18]. Therefore, two kinds of evidence support two opposite views on whether gender diversity affects corporate cash holdings.

One view is that gender diversity is negatively associated with corporate cash holdings. Previous literature reveals no significant effect when Loukil and Yousfi consider R\&D investment, internal growth, investment opportunities, and total risk as measures of risk-taking [19]. Accordingly, women on boards have no significant effect on managerial and strategic risktaking. Company management and the level of risktaking are highly related to cash holding. Thus, gender diversity has no compelling significance on corporate cash holdings. Moreover, Huang finds that the degree of industry competition does not moderate the relationship between board gender diversity and financial performance [2]. That is, the impact of board gender diversity on financial performance is not significantly different between high-competitive industries and lowcompetitive ones. This evidence further proves that gender diversity is probably not related to cash holdings.

The other outcome illustrates adding a new female/minority director to the board is accompanied by significant increases in dividend payouts afterward [20]. Because after the distribution of dividends, the cash holding of the business decreases, gender diversity would counter the negative relationship with the corporate cash holdings. Another research unfolds that female independent directors are tough monitors who play their role in mitigating the agency problem of cash holdings. Moreover, a pronounced negative effect is found on cash holdings of the presence of more than one female director, consistent with the critical mass theory [2]. To test this conclusion, we propose the following hypothesis:

Hypothesis 1a: Gender diversity is negatively associated with corporate cash holdings, ceteris paribus.

The other view is that gender diversity has a positive relationship with corporate cash holdings [12]. For example, Zeng and Wang provide supporting evidence indicating that female CEOs are more conservative than males [12]. In addition, Levi et al. (2014) find that female directors less overestimate merger gains, which indicated that firms with female directors are less likely to make acquisitions and will pay lower bid price if they do [21]. Furthermore, evidence could support that firms 
more likely select the female CEOs with relatively high risk and an expectation of a reduction in risk by reducing the payment of cash [14]. In sum, the above studies lead us to conclude that gender diversity may positively affect corporate cash holdings. Based on the above analysis, we propose the hypothesis as follow:

Hypothesis 1b: Gender diversity is positively associated with corporate cash holdings, ceteris paribus.

\section{DATA AND METHODOLOGY}

\subsection{Sample and data source}

Our initial sample and the main data consist of firms listed on the SHSE and SZSE are collected from the China Stock Market Accounting Research (CSMAR) database covering the period 2011-2017, which is a comprehensive research-oriented database focusing on China's finance and economy. We select 2011 as the initiate year of our sample because the Financial Crisis in 2008 and the following two years might have an inscrutable effect on our empirical results. Following Atif's research, we exclude the special treatment firms (ST) from our sample. Finally, our sample contains 12,505 firm-year observations from 2,408 companies [2]. We obtain the financial information of listed companies from the financial statement and get the board characteristics such as the percentage of females on board to explore the relationship between board gender diversity and corporate cash holdings.

\subsection{Regression model}

Our hypotheses to be tested are that board gender diversity is positively associated with corporate cash holdings. And we use the following baseline regression model:

$$
\begin{aligned}
& \text { Cash }_{i, t+1}=\beta_{0}+\beta_{1}(\text { board gender diversity })_{i, t}+ \\
& \sum_{k} \gamma_{k} \text { ControlVariable }{ }_{k, i, t}+\delta_{2}(\text { Year fixed } \\
& \text { effect } \left.)_{t}+\delta_{3} \text { (Industry fixed effects }\right)_{i}+\varepsilon_{i, t+1}
\end{aligned}
$$

Cash $_{i, t+1}$ measures corporate cash holdings, i represents firm, and t donates year. We use one-year lagged variables as the $t+1$ in consideration that it needs a period for the admission of female board members to impact corporate cash holdings decisions. The $\beta_{1}$ represents regression coefficients; $\varepsilon_{i, t+1}$ is an error term; Where $\gamma_{k}$ is the coefficients of the control variable, and the control variable consists of firm characteristics such as Size ${ }_{t}$, Tobin's $Q_{t}$, return on assets $\left(R O A_{t}\right)$, leverage $\left(L e v_{t}\right)$, book-to-market ratio $\left(B M_{t}\right)$. After confirming the appropriateness of fixed effect by the Hausman test, which shows that random effect is uncorrelated with dependent variables. We use the fixed effect model (FEM) to help us eliminate the omitted variable bias and controls for year effect and industry fixed effects.

\subsection{Variables}

\subsubsection{Dependent variable: Casht +1}

To measure the level of corporate cash holdings we use the ratio of cash and cash equivalents to net value of total assets after deducting cash and cash equivalents.

Cash $=$ cash and cash equivalents/(net value of total assets-cash and cash equivalents)

\subsubsection{Independent variable: Female}

To measure the board gender diversity, according to the prior studies, we employ the percentage of female directors in the total number of directors on the board (Female) [10].

\subsubsection{Control variables}

We control several financial factors that will affect corporate cash holdings have shown in prior studies. The Size $_{t}$ is defined as the natural logarithm of the book value of total assets in year $t$. According to the research of Sorin Gabriel Anton that the firm value increases in the linear form of cash holding, and it decreases in the quadratic form, highlighting an inverted U-shaped curve relationship [22]. On the side, we control for the Tobin's $Q_{t}$, which is representing the firm value that is equal to market value divided by book value in year $t$. Because Do Thi concluded that Tobin's Q as the substitution of firm value has a positive regression coefficient with cash and cash equivalent, which suggests an invert Ushaped relationship between cash holding and firm value [23]. $B M_{t}$, shorts for book-to-market ratio, which is measured as the book value of equity divided by the market value of equity in year $t$, we control for it since a low book-to-market ratio due to a positive change in cash holding [24]. What's more, as there is a significant correlation between variations of return on assets $(R O A)$ and cash holding, we control for the $R O A_{t}$, which is a measure of how much net profit is generated per unit of assets in year $t$. Beyond that, we also control for the financial leverage, the $L e v_{t}$, which can amplify the benefits and risks and equals the book value of total debt divided by the book value of total assets in year $t$, which has been concluded to have a negative effect on the level of cash [2].

\section{EMPIRICAL ANALYSES}

\subsection{Descriptive statistic}

Table 1 presents the summary statistics of gender diversity and descriptive statistics of other variables in our analysis. We find 13.9 percent of directors are females, and the range of Female $t_{t}$ is quite huge. The results show that females make up a small percentage of 
board members, and the proportion of women is also very different from company to company. What's more, the means of the cash measures, $\operatorname{cash}_{t+1}$, are 0.12 , it also has a standard deviation of 0.16 , and our sample is widely sampled in companies with a ratio of cash from 0.001 to 0.842 . The size ${ }_{t}$, Tobin's $Q_{t}$, and the $B M_{t}$ are
$22.52,2.14$, and 0.57 on average, respectively. In addition, the $R O A_{t}$ and $L e v_{t}$ in our sample have an average of 0.05 and 0.37 , respectively. Their ranges are large enough as -0.164 to 0.19 and 0.04 to 0.84 , respectively, which can help us analyze our studies in a wide range of samples.

Table 1. Descriptive statistics of key variables of observed firms

\begin{tabular}{lllllll}
\hline Variable & Obs. & Mean & Std. dev & Minimum & Median & Maximum \\
\hline Cash $_{t+1}$ & 12,505 & 0.120 & 0.161 & 0.001 & 0.060 & 0.842 \\
Female & 12,505 & 0.139 & 0.121 & 0 & 0.111 & 0.833 \\
Size $t$ & 12,505 & 22.52 & 1.127 & 20.58 & 22.38 & 26.19 \\
Tobin's $Q_{t}$ & 12,505 & 2.141 & 1.190 & 0.916 & 1.752 & 7.236 \\
BMt $_{t}$ & 12,505 & 0.573 & 0.222 & 0.138 & 0.571 & 1.092 \\
ROA $_{t}$ & 12,505 & 0.049 & 0.047 & -0.164 & 0.046 & 0.190 \\
Lev $_{t}$ & 12,505 & 0.371 & 0.201 & 0.044 & 0.352 & 0.840
\end{tabular}

\subsection{Correlation analysis}

Table 2 presents the correlations among variables in our regression model to test the multicollinearity problem. We calculated the Pearson and Spearman rank correlation between variables. The result shows that gender diversity is positive with Ratio of cash $_{\mathrm{t}+1}$, which is consistent with our null hypothesis. In addition, the table shows that our independent variables are positive correlated with Tobin's $Q_{t}$ and $R O A_{t}$, while other variables as $\mathrm{Size}_{t}, B M_{t}$ and $L e v_{t}$ is negatively correlated with it.

Furthermore, we test the potential effect of multicollinearity between these coefficients by using the variance inflation factor (VIF) and the largest one of $B M_{t}$ is 4.16 , the overall mean is 2.13 , which is well comply with the rule of thumb cutoff of 10.00 for multiple regression models. Hence, we infer our study has no serious multicollinearity problem.

Table 2. Correlation coefficient

\begin{tabular}{|c|c|c|c|c|c|c|c|}
\hline Variable & $\operatorname{Cash}_{t+1}$ & Female $_{t}$ & Sizet $_{t}$ & Tobin's $Q_{t}$ & $B M_{t}$ & $R O A_{t}$ & Levt \\
\hline $\operatorname{Cash}_{t+1}$ & & 0.002 & $-0.403 * * *$ & $-0.285 * * *$ & $0.285^{* * *}$ & $0.175 * * *$ & $-0.311 * * *$ \\
\hline Female $_{t}$ & $0.018 * *$ & & $-0.130 * * *$ & $0.080 * * *$ & $-0.080 * * *$ & $0.063 * * *$ & $-0.111 * * *$ \\
\hline $\mathrm{Size}_{t}$ & $-0.361 * * *$ & $-0.142 * * *$ & & $-0.033 * * *$ & $0.033 * * *$ & $-0.089 * * *$ & $0.499 * * *$ \\
\hline Tobin's $Q_{t}$ & $-0.257 * * *$ & $0.058 * * *$ & $0.018 * *$ & & $-1.000 * * *$ & $0.264 * * *$ & $-0.310 * * *$ \\
\hline$B M_{t}$ & $0.259 * * *$ & $-0.083 * * *$ & $0.127 * * *$ & $-0.856 * * *$ & & $-0.264 * * *$ & $0.310 * * *$ \\
\hline$R O A_{t}$ & $0.131 * * *$ & $0.053 * * *$ & $-0.022 * *$ & $0.190 * * *$ & $-0.234 * * *$ & & $-0.441 * * *$ \\
\hline$L e v_{t}$ & $-0.349 * * *$ & $-0.109 * * *$ & $0.507 * * *$ & $-0.260 * * *$ & $0.341 * * *$ & $-0.404 * * *$ & \\
\hline
\end{tabular}

Lower-triangular cells report Pearson's correlation coefficients, upper-triangular cells are Spearman's rank correlation

$* * * p<0.01, * * p<0.05, * p<0.1$

\subsection{Univariate analysis}

In the descriptive statistics section exists a large number of firms that have no female directors on the board, so we employ the method of univariate analysis to test the difference between firms with females on board and firms without females on board. The results show in Table 3. 
Table 3. Single factor hypothesis testing

\begin{tabular}{lllllll} 
Variables & G1 $(0)$ & Mean1 & G2(1) & Mean2 & MeanDiff & t-Value \\
\hline Cash $_{t+1}$ & 5254 & 0.109 & 7,251 & 0.127 & -0.018 & $-6.042^{* * *}$ \\
Size $_{t}$ & 5254 & 22.74 & 7,251 & 22.36 & 0.376 & $18.671^{* * *}$ \\
Tobin' $^{\prime} Q_{t}$ & 5254 & 2.071 & 7,251 & 2.192 & -0.121 & $-5.626^{* * *}$ \\
BM $_{t}$ & 5254 & 0.594 & 7,251 & 0.558 & 0.036 & $8.877^{* * *}$ \\
ROA $_{t}$ & 5254 & 0.045 & 7,251 & 0.052 & -0.007 & $-7.931^{* * *}$ \\
Lev $_{t}$ & 5254 & 0.401 & 7,251 & 0.350 & 0.051 & $14.140^{* * *}$ \\
\hline
\end{tabular}

G1 is a group which firms without female directors

G2 is a group which firms with female directors

Table 3 presents the results of univariate tests of independent variables in our studies, which is the gender diversity. The Female $_{t}$ is a dummy variable equal to 1 when the firm has female directors on the board and 0 when the firm has no female directors on the board. This approach led us to divide our samples into 5,254 without female directors and 7,251 with female directors. As Table 3 showed, the mean of $\mathrm{Cash}_{t+1}$ is 0.109 for the firms without female directors and 0.127 for the firms with female directors. The differences are statistically significant at the $1 \%$ level, suggesting these two groups are significantly different. In addition, the variables of Tobin's $Q_{t}$ and $R O A_{t}$ have the same change with $\mathrm{Cash}_{t+1}$ when firms with or without female directors while others variable as Size $t, B M_{t}$ and $L e v_{t}$ are, on the contrary, which consistent with results we figure in part of correlation analysis.

\subsection{Baseline results}

In the last part of the Univariate analysis, we studied the difference between firms with female directors and firms without female directors. In consideration of control variables such as Size $_{t}$, Tobin's $Q_{t}, B M_{t}, R O A_{t}$, and $\operatorname{Lev}_{t}$ may impact our dependent variables, which is the cash holdings. Hence, employing the panel data fixed effect model to test our hypotheses, controlling for industry and year effects.

As shown in Table 4, the independent variable female coefficients are both positive and statistically significant at the 5\% level. And the coefficients of the control variables are consistent with prior studies, as the firms with smaller size, lower Tobin's Q, lower leverage, and higher book-to-market ratio, higher return on assets are associated with higher cash holdings [2].

This result can support our hypotheses that cash holdings are positive correlation with the gender diversity of boards, which is consistent with prior studies that due to a much higher percentage of females versus males (more than half), firms tend to be more conservatism, which leading higher corporate cash holdings.

Table 4. ordinary least squares regression

\begin{tabular}{|c|c|c|}
\hline VARIABLES & $\begin{array}{c}\text { (1) } \\
\text { Cash }_{t+1}\end{array}$ & $\begin{array}{c}\text { (2) } \\
\text { Cash }_{t+1}\end{array}$ \\
\hline Femalet & $\begin{array}{l}0.063 * * * \\
(5.023)\end{array}$ & $\begin{array}{l}0.022 * * \\
(2.003)\end{array}$ \\
\hline Size $_{t}$ & & $\begin{array}{l}-0.025 * * * \\
(-14.609)\end{array}$ \\
\hline Tobin's $Q_{t}$ & & $\begin{array}{l}-0.004^{*} \\
(-1.884)\end{array}$ \\
\hline$B M_{t}$ & & $\begin{array}{l}0.332 * * * \\
(29.844)\end{array}$ \\
\hline$R O A_{t}$ & & $\begin{array}{l}0.190 * * * \\
(6.731)\end{array}$ \\
\hline Levt & & $\begin{array}{l}-0.292 * * * \\
(-31.921)\end{array}$ \\
\hline Constant & $\begin{array}{l}0.190 * * * \\
(12.567)\end{array}$ & $\begin{array}{l}0.700 * * * \\
(18.398)\end{array}$ \\
\hline Year fixed effects & Yes & Yes \\
\hline Industry fixed effects & Yes & Yes \\
\hline Observations & 12,505 & 12,505 \\
\hline Adjusted $\mathrm{R}^{2}$ & 0.329 & 0.510 \\
\hline Number of stkcd & 2,408 & 2,408 \\
\hline
\end{tabular}




\section{ROBUSTNESS TESTS}

There exist some challenges of potential fixed effect created by firm-specific characteristics and different methods to measure cash holdings for our study have to face. Hence, we employ the fixed effects model to test firm fixed effects and use the regression to test the impact of different methods to measure corporate cash holdings, which is measured as money fund dividend by net value of total assets deducting the money fund. We set it as $\mathrm{Cash}_{t_{+1}}$ in our analysis.

Table 5. robustness tests of firm fixed effects and different methods to measure cash holdings

\begin{tabular}{lll}
\hline \multirow{2}{*}{ VARIABLES } & $(1)$ & $(2)$ \\
\hline Female & Cash $_{t+1}$ & Cash $_{t+1}$ \\
& $0.047^{* * *}$ & $0.020^{*}$ \\
Size $t$ & $(2.964)$ & $(1.721)$ \\
& $-0.030^{* * *}$ & $-0.017^{* * *}$ \\
Tobin's $Q_{t}$ & $(-8.584)$ & $(-9.381)$ \\
& -0.002 & $-0.005^{* *}$ \\
BMt & $(-1.220)$ & $(-2.425)$ \\
& $0.384^{* * *}$ & $0.374^{* * *}$ \\
ROA $t$ & $(30.569)$ & $(33.168)$ \\
& $0.201^{* * *}$ & $0.235^{* * *}$ \\
Lev $t$ & $(6.059)$ & $(8.164)$ \\
& $-0.299^{* * *}$ & $-0.336^{* * *}$ \\
Constant & $(-23.788)$ & $(-35.412)$ \\
& $0.779^{* * *}$ & $0.519^{* * *}$ \\
Year fixed effects & $(10.531)$ & $(12.831)$ \\
Industry fixed effects & Yes & Yes \\
Firm fixed effects & Yes & No \\
Observations & Yes & Yes \\
Adjusted R ${ }^{2}$ & 12,505 & 12,505 \\
Number of stkcd & 0.512 & 0.507 \\
& 2,408 & 2,408 \\
\hline
\end{tabular}

As shown in Table 5, we re-estimate the regression of the model by adding the firm fixed effects. The results show that the coefficients on the independent variable Female in the table are much significant and positive, which suggests that our results are robust when we control for firm fixed effects. We suggest it related to the significant difference in the gender diversity among different firms.

For the different methods to measure corporate cash holdings, Table 5 shows a significantly positive impact of board gender diversity on corporate cash holdings. The results indicate the cash holdings measure does not change our results.

\section{HETEROGENEITY ANALYSIS}

Our analyses in the previous part are based on the control variables of some firm characteristics as Size, Tobin's $Q_{t}, B M_{t}, R O A_{t}, \operatorname{Lev}_{t}$ and fixed effects of years, industries, and firms. We also focus on some heterogeneity factors like whether the firm belongs to SOEs or whether the firm is audited by the Big four (KPMG, PwC, DTT, E\&Y). The above tests will help us to understand the impact of board gender diversity on corporate governance more precisely and comprehensively.

As Table 6 shows, the effect of having female directors on boards was more pronounced in non-SOEs. We conjecture SOEs are so steady on financial conditions themselves that the effect of females on cash holdings is less significant. Meanwhile, we also find that having female directors on boards is more pronounced among the non-Big 4 firms, which may due to the firm perform better in financial conditions by increasing their cash holdings for tighter external regulation.

Table 6. the effect of having females on boards on SOEs and Big four regulated firms

\begin{tabular}{|c|c|c|c|c|}
\hline & (1) & $(2)$ & (3) & (4) \\
\hline & SOEs & Non-SOEs & Big 4 & Non-Big 4 \\
\hline VARIABLES & $\operatorname{Cash}_{t+1}$ & $\operatorname{Cash}_{t+1}$ & $\operatorname{Cash}_{t+1}$ & $\operatorname{Cash}_{t+1}$ \\
\hline \multirow[t]{2}{*}{ Female $_{t}$} & $0.024 *$ & $0.050 * *$ & $0.025 * *$ & 0.029 \\
\hline & $(1.861)$ & $(2.444)$ & $(2.152)$ & -0.683 \\
\hline \multirow[t]{2}{*}{ Size $_{t}$} & $-0.022 * * *$ & $-0.021 * * *$ & $-0.025 * * *$ & $-0.018 * * *$ \\
\hline & $(-9.623)$ & $(-7.439)$ & $(-13.015)$ & $(-3.487)$ \\
\hline \multirow[t]{2}{*}{ Tobin's $Q_{t}$} & -0.001 & $-0.009 * * *$ & -0.002 & -0.01 \\
\hline & $(-0.257)$ & $(-3.103)$ & $(-1.152)$ & $(-1.536)$ \\
\hline \multirow[t]{2}{*}{$B M_{t}$} & $0.357 * * *$ & $0.200 * * *$ & $0.344 * * *$ & $0.104 * * *$ \\
\hline & $(24.859)$ & $(13.132)$ & $(29.461)$ & -3.349 \\
\hline$R O A_{t}$ & $0.192 * * *$ & $0.155 * * *$ & $0.191 * * *$ & 0.028 \\
\hline
\end{tabular}




\begin{tabular}{lllll} 
& $(5.681)$ & $(3.518)$ & $(6.571)$ & -0.264 \\
Lev $t$ & $-0.311^{* * *}$ & $-0.157^{* * *}$ & $-0.296^{* * *}$ & $-0.182^{* * *}$ \\
& $(-28.36)$ & $(-10.137)$ & $(-31.397)$ & $(-4.949)$ \\
Constant & $0.640^{* * *}$ & $0.582^{* * *}$ & $0.690^{* * *}$ & $0.534 * * *$ \\
& $(12.773)$ & $(9.232)$ & $(16.408)$ & -3.993 \\
Year fixed effects & Yes & Yes & Yes & Yes \\
Industry fixed effects & Yes & Yes & Yes & Yes \\
Adjusted R & 0.566 & 0.287 & 0.517 & 0.254 \\
Observations & 9,138 & 3,367 & 11,852 & 653 \\
Number of stkcd & 1,927 & 526 & 2,326 & 138 \\
\hline
\end{tabular}

\section{CONCLUSIONS}

This study enlarges the extant literature about the effect of board gender diversity on corporate cash holdings of listed companies in China. Our results suggest that the percentage of female directors is positively associated with cash holdings. Moreover, we find that the book-to-market ratio and ROA also have positive impacts on cash holdings. In contrast, firm size, Tobin's Q, and financial leverage have negative correlations with cash holdings. In addition, we find that the positive effect on cash holdings made by gender diversity is more prominent for non-SOEs and non-Big 4 firms.

Recently, regulators have continuously put pressure on companies in developing capital markets to increase the gender diversity of the board of directors. Our research results provide strong empirical supports for this notion. We suggest that companies should increase the proportion of female directors and promote gender diversity. For state-owned enterprises and firms not audited by Big 4 auditors, paying more attention to gender diversity is undoubtedly an effective approach to improve corporate governance.

\section{REFERENCES}

[1] Carter, D.A., Simkins, B.J. and Simpson, W.G., 2003. Corporate Governance, Board Diversity, and Firm Value. The Financial Review, 38: 33-53.

[2] Muhammad Atif, Benjamin Liu, Allen Huang., 2019. Does board gender diversity affect corporate cash holding? Journal of Business Finance \& Accounting; Oxford Vol. 46, lss. 7-8, (Jul/Aug 2019): 1003-1029.

[3] The Economists. 2021. Is the lot of female executives improving? https://www.economist.com/graphicdetail/2021/03/04/is-the-lot-of-female-executivesimproving

[4] Bertrand, M., Sandra E., Sissel B., Adriana J and Muney, L., 2019. Breaking The Glass Ceiling? The
Effect of Board Quotas On Female Labor Market Outcomes In Norway. The Review of Economic Studies, 86: 191-239.

[5] The Economists. 2018. Are gender quotas good for business? https://www.economist.com/theeconomist-explains/2018/09/03/are-gender-quotasgood-for-business

[6] Campbell, S., 2019. The Effect of CEO Gender on Corporate Cash Holdings within Indian Firms.

[7] Yuhui, W., 2020. Does Board Gender Diversity Bring Better Financial and Governance Performances? An Empirical Investigation of Cases in Taiwan. Sustainability 12, no. 8: 3205.

[8] Couderc, N., 2004. Corporate cash holdings: financial determinants and corporate governance.

[9] Amess, K., Banerji, S and Lampousis, A., 2015. Corporate Cash Holdings: Causes and Consequences. International Review of Financial Analysis, 42: 421-433.

[10] Dittmar, A., Mahrt-Smith, J and Servae, H., 2003. International Corporate Governance and Corporate Cash Holdings. The Journal of Financial and Quantitative Analysis, 38: 111-133.

[11] Kariuki, S, N., 2015. Determinants of Corporate Cash Holdings: Evidence From Private Manufacturing Firms In Kenya. International Journal of Advanced Research in Management and Social Sciences, 4: 15-33.

[12] Zeng, S., \& Wang, L. (2015). CEO gender and corporate cash holdings. Are female CEOs more conservative? Asia-Pacific Journal of Accounting \& Economics, 22, 449-474.

[13] Barber, B.M. and T. Odean, "Boys will be Boys: Gender, Overconfidence, and Common Stock Investment," Quarterly Journal of Economics (February 2001), pp. 261-292.

[14] Martin, Anna D; Nishikawa, Takeshi; Williams, Melissa A., 2009. CEO Gender: Effects on 
Valuation and Risk. Quarterly Journal of Finance and Accounting: QJFA; Omaha Vol. 48, Iss. 3, (Summer 2009): 23-40.

[15] Cox, T. H., \& Blake, S. (1991). Managing cultural diversity: Implications for organizational competitiveness. The Executive, 5, 45-56.

[16] Abbott, L.J., Parker, S. and Presley, T.J.(2012), "Female board presence and the likelihood of financial restatement", Accounting Horizons, Vol.26 No.4, pp.607-629.

[17] Ittonen, K., Vahamaa, E., \& Vahamaa, S. (2013). Female auditors and accruals quality. Accounting Horizons, 27(2), 205-228.

[18] Jianakoplos, N. A., \& Bernasek, A. (1998). Are women more risk averse? Economic Inquiry, 36(4), 620-630.

[19] Loukil, Nadia; Yousfi, Ouidad; Raissa Wend-kuuni Yerbanga. (2019). Does gender diversity on boards reduce information asymmetry problems? Empirical evidence from the French market. Journal of Family Business Management; Bingley Vol. 10, Iss. 2, (2019): 144-166.
[20] S. Byoun, K. Chang, Y. S. Kim, Does Corporate Board Diversity Affect Corporate Payout Policy, Asia-Pacific journal of financial studies, 45(2016) $48-101$.

[21] Levi, Maurice; Li, Kai; Zhang, Feng. (2014). Director gender and mergers and acquisitions. Journal of Corporate Finance; Amsterdam Vol.28, (Oct 2014): 185.

[22] Anton, Sorin Gabriel; Nucu, Anca Elena Afloarei. Firm value and corporate cash holdings. Empirical evidence from the polish listed firms. E+M Ekonomie a Management; Liberec Vol. 22, Iss. 3, (2019): 121-134.

[23] Thanh Nhan, Do Thi; Ha, Pham. Cash Holding, State Ownership and Firm Value: The Case of Vietnam. International Journal of Economics and Financial Issues, Special Issue; Mersin Vol. 6, Iss. 6S, (2016).

[24] Sodjahin, William R. Change in Cash-Holding Policies and Stock Return Predictability in the Cross Section. Financial Analysts Journal; Charlottesville Vol. 69, Iss. 1, (Jan/Feb 2013): 5370 . 